\title{
Potensi Usaha dan Analisis Nilai Tambah Pemasaran Ayam Kampung di Gorontalo
}

\author{
Serli Anas, Dwi Rohmadi dan Andi Yulyani Fadwiwati \\ Balai Pengkajian Teknologi Pertanian Gorontalo \\ Jl. Moh. Van Gobel No. 270 Desa Iloheluma, Kec. Tilong Kabila, Kab. Bone Bolango, Gorontalo 96183 Telp/Fax. (0435) 827-627 \\ Email : serli.anasbptpgtlo@gmail.com
}

\begin{abstract}
Abstrak
Usaha ayam kampung pedaging di Provinsi Gorontalo merupakan usaha potensial yang mempunyai nilai ekonomi tinggi dan memiliki potensi untuk terus dikembangkan. Dilihat dari sisi permintaan pasar, jumlah penduduk yang besar dan kenaikan pendapatan merupakan faktor utama yang mempengaruhi permintaan. Perkembangan populasi ayam kampung di Provinsi Gorontalo sangat meningkat dari tahun ketahun. Berdasarkan data Statistik Peternakan dan Kesehatan Hewan bahwa pada tahun 2016 populasi ayam kampung sebanyak 1.440.567 ekor lebih tinggi $0.96 \%$ dibandingkan pada tahun 2015 sebanyak 1.376 .518 ekor, begitupun dengan produksi daging ayam kampung tahun 2016 sebesar 1.586 ton lebih tinggi 0,96\% dibandingkan pada tahun 2015 sebesar 1.516 ton. Pemasaran ayam kampung selain dijual langsung ke konsumen juga melibatkan beberapa lembaga pemasaran, aktivitas pemasaran yang dilakukan dari peternak hingga ke konsumen akhir akan menciptakan nilai tambah yang menguntungkan. Tujuannya yaitu untuk mengetahui potensi usaha dan nilai tambah dari pemasaran ayam kampung di Provinsi Gorontalo. Pengkajian ini dilaksanakan di Provinsi Gorontalo Februari Desember 2016. Pengumpulan data berupa data primer dan data sekunder, metode yang digunakan yaitu survey yang bersifat deskriptif. Analisis deskriptif digunakan untuk menggambarkan karakteristik pelaku pemasaran dan saluran pemasaran ayam kampung. Metode analisis nilai tambah menggunakan metode Hayami. Keuntungan yang didapatkan akan semakin besar apabila input produksi dapat ditekan seminimal mungkin termasuk dari pengunaan pakan pada ayam kampung.
\end{abstract}

Kata Kunci : Potensi Usaha, Nilai Tambah, Ayam Kampung

\section{Pendahuluan}

Usaha ayam kampung pedaging di Provinsi Gorontalo merupakan usaha potensial yang mempunyai nilai ekonomi tinggi dan memiliki potensi untuk terus dikembangkan. Dilihat dari sisi permintaan pasar, jumlah penduduk yang besar dan kenaikan pendapatan merupakan faktor utama yang mempengaruhi permintaan. Berdasarkan data BPS bahwa pada tahun 2016 produksi daging ayam kampung sebesar 1.490 ton lebih rendah 1,69\% dibandingkan pada tahun 2015 sebesar 1.516 ton. Program nasional saat ini yang dicanangkan HIMPULI (Himpunan Peternak Unggas Lokal Indonesia) yang disepakati Dirjen Peternakan mencanangkan konsumsi ayam lokal yang semula $16 \%$ dari total populasi unggas akan ditingkatkan menjadi $25 \%$.

Perkembangan populasi ayam kampung di Provinsi Gorontalo sangat meningkat dari tahun ketahun, pada tahun 2004 populasi ayam kampung sebanyak 873.074 ekor dan pada tahun 2008 sebanyak 1.093.422 ekor. Hal ini dapat disimpulkan bahwa ayam kampung merupakan sumber penghasilan yang cukup menjanjikan, tak heran jika makin hari semakin banyak orang yang tertarik memeliharanya (Rasyaf, M, 2011).
Pemerintah pun amat mendukung peternakan ayam kampung. Gerakan Intab (Intensifikasi Ayam Buras) yang dicanangkan pemerintah merupakan perwujudan keinginan memajukan ternak ini (Nawawi dan Nurrohmah, 2011).

Pemasaran ayam kampung selain dijual langsung ke konsumen juga melibatkan beberapa lembaga pemasaran, aktivitas pemasaran yang dilakukan dari peternak hingga ke konsumen akhir akan menciptakan nilai tambah yang menguntungkan. Nilai tambah yang dihasilkan mempunyai daya tarik tersendiri dalam usaha pemasaran ayam kampung, sehingga perlunya dilakukan analisis nilai tambah untuk mengetahui potensi usaha pemasaran ayam kampung di provinsi Gorontalo.

Di provinsi Gorontalo semakin banyaknya usaha rumah makan yang menyediakan makanan yang berasal dari ayam kampung sehingga makin banyak peminat rumah makan yang membutuhkan ketersediaan ayam kampung. Di Provinsi Gorontalo kenaikan harga ayam kampung terus terjadi, terutama menjelang bulan ramadhan dan lebaran Idul Fitri. Harga ayam kampung di Gorontalo melonjak dari Rp 65 ribu per ekor menjadi Rp 90 ribu hingga Rp 100 ribu rupiah per ekor. Hal itu terjadi karena minat masyarakat terhadap ayam kampung 
sangat tinggi, namun pasokan yang ada belum mencukupi.

Semakin banyaknya usaha peternakan ayam kampung baik skala rumah tangga, skala kecil maupun skala besar maka semakin terpenuhinya kebutuhan pangan protein hewani keluarga dan semakin terpenuhi pula kebutuhan rumah makan akan pasokan ayam kampung. Ini disebabkan karena semakin banyak peminat usaha beternak ayam kampung sehingga pendapatan yang diperoleh semakin baik.

\section{Tujuan}

Mengetahui potensi usaha dan analisis nilai tambah pemasaran ayam kampung di Provinsi Gorontalo.

\section{Sasaran}

Meningkatnya potensi usaha dan nilai tambah pemasaran ayam kampung di Provinsi Gorontalo

\section{Luaran Hasil Pengkajian}

Besarnya potensi usaha dan nilai tambah pemasaran ayam kampung di Provinsi Gorontalo

\section{Metode Penelitian \\ Pendekatan}

Pengkajian telah dilaksanakan di Provinsi Gorontalo selama bulan Januari sampai dengan Desember 2016. Bekerjasama dengan stakeholder terkait, lembaga pemasaran dan kelompok ternak ayam. Pengkajian meliputi survey proses pemasaran ayam kampung di Provinsi Gorontalo.

\section{Ruang Lingkup Kegiatan}

1. Studi Pustaka Mengumpulkan data sekunder dari berbagai buku, laporan, jurnal, website serta bahan lain

2. Persiapan

Pembuatan kuisioner, diskusi dengan pihak terkait, mengatur jadwal untuk penelitian dan wawancara.

3. Pelaksanaan Kegiatan di Lapangan

Wawancara, observasi dan pengumpulan data sekunder pendukung

4. Pengumpulan dan Pengolahan/Analisis Data

Pengumpulan data primer dan data sekunder, metode yang digunakan yaitu survey yang bersifat deskriptif

5. Pelaporan

Laporan pengkajian meliputi laporan perkembangan kegiatan per triwulan, per semester dan laporan akhir. Laporan akhir dibuat setelah pengkajian selesai dilaksanakan.

\section{Bahan dan Metode Pelaksanaan Kegiatan}

\section{Bahan}

Bahan yang digunakan dalam pengkajian ini yaitu data primer (kuisioner) dan data sekunder (study pustaka) dan alat tulis

\section{Metode Pelaksanaan Pengkajian}

Penelitian ini dilakukan dengan metode survey yang bersifat deskriptif, data yang digunakan dalam penelitian ini adalah data primer dan data sekunder. Data primer diperoleh dari pengamatan langsung dan wawancara dengan peternak breeder, pedagang pengumpul, lembaga pemasaran serta narasumber lain yang berkaitan dengan penelitian. Data sekunder diperoleh dari berbagai buku, laporan laporan, jurnal, website serta bahan lain.

\section{Metode Analisis}

Analisis deskriptif digunakan untuk menggambarkan karakteristik pelaku pemasaran dan saluran pemasaran ayam kampung. Metode analisis nilai tambah menggunakan metode Hayami et al (1987). Metode ini merupakan analisis nilai tambah yang sering digunakan untuk komodiats pertanian. Analisis nilai tambah pada proses pengolahan menghasilkan informasi antara lain :

1. Nilai tambah (Rp).

2. Rasio nilai tambah terhadap nilai produk yang dihasilkan (\%), menunjukkan persentase nilai tambah dari nilai produk.

3. Balas jasa dari tenaga kerja (Rp), menunjukkan upah yang diterima tenaga kerja langsung untuk memperoleh satu satuan bahan baku.

4. Bagian tenaga kerja (\%), menunjukkan persentase imbalan tenaga kerja dari nilai tambah.

5. Keuntungan (Rp), menunjukkan bagian yang diterima pemilik faktor produksi karena menanggung resiko usaha.

6. Tingkat keuntungan (\%), menunjukkan persentase keuntungan terhadap nilai tambah.

7. Marjin, menunjukkan besarnya kontribusi pemilik faktor produksi selain bahan baku yang digunakan dalam proses produksi.

\section{Hasil dan Pembahasan}

\section{Saluran Pemasaran Ayam Kampung}

Ayam kampung yang dijual hingga ke tangan konsumen melibatkan berbagai lembaga pemasaran. Lembaga pemasaran tersebut melibatkan peternak sebagai produsen, pedagang pengumpul dan konsumen lembaga (rumah makan). Penelitian terhadap saluran pemasaran ayam kampung ini diawali dari peternak sebagai produsen, lalu ditelusuri dijual kemana saja ayam kampung yang diproduksi.

Hasil penelitian menunjukkan bahwa terdapat tiga saluran pemasaran ayam kampung yang dilalui mulai dari produsen hingga sampai ke tangan konsumen di provinsi Gorontalo, yaitu : 
1. Produsen $\rightarrow$ Pedagang Pengecer Konsumen Rumah Tangga

2. Produsen $\rightarrow$ Pedagang Pengumpul Pedagang Pengecer $\rightarrow$ Konsumen Rumah Tangga

3. Produsen $\rightarrow$ Pedagang Pengumpul Konsumen Lembaga Tangga

\section{Produsen $\rightarrow$ Konsumen Rumah Tangga}

Produsen (peternak) menyalurkan produknya ke Pedagang pengumpul, pedagang pengecer dan konsumen rumah tangga. Pedangang pengumpul maupun pedagang eceran datang ke tempat produsen untuk mengambil produk dalam bentuk ayam hidup. Pedagang pengecer langsung menjual produk ke konsumen rumah tangga di pasar-pasar tradisional maupun pasar induk. Pedagang pengumpul menyalurkan produknya dengan dua saluran. Pertama, menyalurkan kepada pedagang pengecer yang kemudian menjualnya ke konsumen rumah tangga di pasar-pasar tradisional maupun pasar induk (sentral). Kedua, menyalurkan kepada konsumen lembaga (rumah makan) yang langsung diantarkan ke konsumen lembaga dalam bentuk ayam hidup. Konsumen lembaga kemudian mengolah ayam hidup menjadi produk ayam siap santap untuk kemudian dijual kepada konsumen rumah tangga. Produsen juga menjual ayam kampung dalam bentuk hidup ke pasar-pasar tradisional maupun pasar induk, produsen ini merupakan peternak skala rumah tangga yang ternak ayamnya masih dalam jumlah sedikit yang dapat dijual langsung ke pasaran tanpa melalui pedagang pengumpul ataupun pedagang pengecer.

\section{Analisis Nilai Tambah}

Marjin, nilai tambah dan keuntungan yang didapatkan oleh tiap pelaku pemasaran tentunya berbeda-beda. Sumber-sumber nilai tambah diperoleh dari pemanfaatan factor-faktor produksi dan input seperti tenaga kerja, modal, sumber daya alam dan manajemen. Analisis nilai tambah tidak hanya melihat besar nilai tambah yang didapat dari pemasaran, tetapi juga distribusi dan pemanfaatan factor produksi yaitu tenaga kerja, modal sumber daya alam dan manajemen.
Tabel 1. Komponen Nilai Tambah Ayam Kampung Per Hari

\begin{tabular}{|c|c|c|}
\hline \multicolumn{2}{|c|}{ Ayam (Ekor) } & \multirow{2}{*}{$\begin{array}{c}\text { Nilai Tambah } \\
\text { (Rp/ekor) }\end{array}$} \\
\hline Input & Output & $11,100-40,340$ \\
\hline $5-350$ & $5-350$ & 100 \\
\hline
\end{tabular}

Tabel 1 memperlihatkan bahwa peternak ayam kampung memelihara ayam kampung dalam bentuk starter kemudian dipelihara sampai menjadi finisher siap panen dalam kisaran 5 - 350 ekor. Nilai tambah yang didapat peternak berada pada kisaran Rp 11,100 - 40,340.

Factor koefisien tenaga kerja dalam metode ini berdasarkan Harian Kerja Pria (HKP). Koefisien tenaga kerja rata-rata pada peternak ayam kampung sebesar 0,028 HKP per ekor. Hal ini menandakan bahwa dibutuhkan 0,028 HKP atau waktu 0,224 jam untuk memasarkan satu ekor ayam kampung. Berdasarkan saluran pemasaran ayam kampung dapat terlihat bahwa peternak sebagai responden ini merupakan peternak utama dan peternak skala rumahan, bagi peternak skala rumahan dapat langsung menjual produk beruapa ayam hidup ke konsumen rumah tangga melalui pasar-pasar karena jumlahnya yang sedikit.

Nilai output didapat dari perkalian antara variable harga output (harga jual) dengan factor konversi. Nilai output rata-rata ayam kampung di peternak adalah Rp 31.667 per ekor.

Nilai tambah pemasaran ayam kampung di dapat dari pengurangan nilai output dengan variabel harga input bahan baku dan sumbangan input lain. Komponen yang termasuk sumbangan input lain adalah biaya pakan, biaya listrik, biaya air, biaya sewa tempat, biaya retribusi dan biaya transportasi. Harga input bahan baku merupakan harga beli ayam hidup. Rata-rata nilai tambah ayam pada peternak ayam kampung sebesar Rp12.142 dengan rasio nilai tambah sebesar 32\% dari harga output. Hal ini disebabkan beberapa peternak memelihara sendiri ayam yang dijualnya dari bentuk starter hingga berumur dua bulan lalu dipanen (dijual), sehingga harga input bahan baku relative kecil, berbeda jauh dibandingkan harga output yang didapatkan. 
Tabel 2. Rata-rata Nilai Tambah Pemasaran Ayam Kampung pada Pelaku Pemasaran

\begin{tabular}{|r|r|}
\hline Variabel Nilai Tambah & \\
\hline I. $\quad$ Output, Input, Harga : & 30,42 \\
1. Output (ekor/hari) & 30,42 \\
2. Input (ekor/hari) & 0,88 \\
3. Tenaga Kerja (HKP/hari) & 1 \\
4. Faktor Konversi (1:2) & 0,028 \\
5. Koefisien Tenaga Kerja (3:2) & 31.677 \\
6. Harga Output (Rp/ekor) & 8.112 \\
7. Upah rata-rata Tenaga Kerja (Rp/HKP) & \\
II. Pendapatan dan Keuntungan & 9.492 \\
8. Harga Input (Rp/ekor) & 10.041 \\
9. Sumbangan Input Lain (Rp/ekor) & 31.677 \\
10. Nilai Output (Rp/ekor) & 12.142 \\
11. A. Nilai Tambah (Rp/ekor) & 32 \\
B. Rasio Nilai Tambah (\%) & 532,86 \\
12. A. Imbalan Tenaga Kerja (Rp/ekor) & 0,02 \\
B. Bagian Tenaga Kerja (\%) & 11.610 \\
13. A. Keuntungan (Rp/ekor) & 31 \\
B. Tingkat Keuntungan (\%) & \\
\hline III. Balas Jasa dari Pemilik Faktor Produksi & 22.184 \\
14. Margin (Rp/ekor) & 0,27 \\
A. Pendapatan Tenaga Kerja (\%) & 25,54 \\
B. Sumbangan Input Lain (\%) & 3,84 \\
\hline C. Keuntungan Perusahaan (\%) & \\
\hline
\end{tabular}

Imbalan tenaga kerja merupakan hasil perkalian dari koefisien tenaga kerja dengan upah rata-rata tenaga kerja. Imbalan tenaga kerja pada peternak ayam kampung sebesar Rp 532,86 per ekor dengan presentase bagian tenaga kerja sebesar $0,02 \%$ dari harga output yang didapatkan.

Keuntungan merupakan selisih antara nilai tambah dengan pendapatan tenaga kerja sehingga dengan kata lain keuntungan merupakan nilai tambah bersih atau bagian yang diterima. Keuntungan yang diterima oleh peternak ayam kampung sebesar Rp 11.610 per ekor dengan persentase keuntungan yang diterima sebesar $31 \%$ dari harga output.

\section{Kesimpulan}

Nilai tambah pemasaran ayam kampung di Provinsi Gorontalo sebesar Rp 12.142 per ekor dengan persentase sebesar $32 \%$ dari harga output produksi. Keuntungan yang diperoleh sebesar Rp 11.610 per ekor dengan persentase sebesar $31 \%$. Keuntungan yang didapatkan akan semakin besar apabila input produksi dapat ditekan seminimal mungkin termasuk dari pengunaan pakan pada ayam kampung.

\section{Daftar Pustaka}

Hayami, Y.T, Kawagoe. Y, Marooka dan M., Siregar. 1987. Agricultural Marketing and Processing in Upland Java, a Perspective From a Sunda Village. CEPRT. Bogor.

Nawawi, N.T dan S. Nurrohmah. 2011. Pakan Ayam Kampung. Penebar Swadaya, Jakarta.

Prasetyo, E. 2012. Agribisnis Ayam Potong Lokal (Ayam Hibrida) di Kabupaten Batang Provinsi Jawa Tengah. Universitas Diponegoro, Semarang.

Rasyaf, M. 2011. Beternak Ayam Kampung. Penebar Swadaya, Jakarta.

Tambunan, R.D. dan Silalahi, M. 2008. Teknologi Budidaya Ayam Buras. Balai Besar Pengkajian dan Pengembangan Teknologi Pertanian. Departemen Pertanian, Bogor.

Wulandari, S. 2008. Analisis Nilai Tambah Pemasaran Ayam Broiler di Wilayah Jakarta Timur. IPB, Bogor. 